\title{
Evaluation of SEBS Algorithm for Estimation of Daily Evapotranspiration Using Landsat-8 Dataset in a Semi-Arid Region of Central Iran
}

\author{
Mohsen Mohammadian ${ }^{1}$, Ramin Arfania1, Hossein Sahour ${ }^{2}$ \\ ${ }^{1}$ Department of Geology, Isfahan (Khorasgan) Branch, Islamic Azad University, Isfahan, Iran \\ ${ }^{2}$ Department of Geosciences, Western Michigan University, Kalamazoo, Michigan, USA \\ Email:^mohsen.mohammadiaan@yahoo.com,rarfania@gmail.com, hossein.sahour@yahoo.com
}

How to cite this paper: Mohammadian, M., Arfania, R. and Sahour, H. (2017) Evaluation of SEBS Algorithm for Estimation of Daily Evapotranspiration Using Landsat-8 Dataset in a Semi-Arid Region of Central Iran. Open Journal of Geology, 7, 335-347.

https://doi.org/10.4236/ojg.2017.73023

Received: January 13, 2017

Accepted: March 27, 2017

Published: March 30, 2017

Copyright $\odot 2017$ by authors and Scientific Research Publishing Inc. This work is licensed under the Creative Commons Attribution International License (CC BY 4.0).

http://creativecommons.org/licenses/by/4.0/

(c) $\underset{\mathrm{EY}}{0}$ Open Access

\begin{abstract}
Evapotranspiration is one the most important parameters in the hydrological cycle and plays a significant role in energy balance of the earth's surface. Traditional field-based measurements approaches for calculation of daily evapotranspiration are valid only for local scales. Using advanced remote sensing technology, the spatial distribution of evapotranspiration may now be quantified more accurately. At the present study, daily evapotranspiration is estimated using Landsat 8 datasets based on the Surface Energy Balance System (SEBS) algorithm over the Zayanderud Dam area in central Iran. For this purpose, three Landsat 8 datasets in the years 2013, 2014 and 2015 covering the study area were atmospherically corrected using the FLAASH approach. The biophysical parameters of the earth's surface for SEBS algorithm, such as normalized difference vegetation index (NDVI), Leaf area index (LAI), fractional vegetation cover (FC) were extracted from the visible and near infrared bands and land surface temperature was computed from thermal bands the Landsat 8 datasets. The spatial distribution of daily ET was provided separately for each year. In addition to the SEBS algorithm, the Penman-Monteith method was applied to estimate the daily ET from meteorological datasets which was obtained from two synoptic stations within the study area. Finally, the simulated daily ET values from both SEBS and Penman-Monteith method were compared to observed values obtained from a lysimeter within the study area. Although the estimated results from both SEBS and Penman-Monteith show a strong correlation with the observed values, the derived ET maps and following analysis demonstrated SEBS has higher accuracy and strength in estimation of daily ET in Zayanderud Dam region.
\end{abstract}

\section{Keywords}

Evapotranspiration, SEBS, Penman-Monteith, Landsat 8, Arid and Semi-Arid 
Regions

\section{Introduction}

Evapotranspiration (ET) term is used to describe the movement of water from the Earth's surface to the atmosphere by the combined processes of evaporation and transpiration. Evapotranspiration (ET) is an important variable in hydrological cycle and one of the key factors for water resources management in arid and semi-arid countries like Iran where water deficiency is becoming a serious challenge on sustainable development and welfare. Moreover, the annual ET rate in Iran has been increased during past decades [1] which can be contributed to water scarcity problems. Reliable estimation of daily evapotranspiration is essential for improving the efficiency of the water supply systems [2].

In general, there are four different methods for estimating ET: hydrological methods (water balance), direct measurement using instruments such as lysimeters, micro-meteorological techniques (energy balance), and empirical or combination methods [3].

Accurate estimation of spatially averaged ET is a challenging task. Traditional field-based ET measurement approaches are limited to specific areas [4]. Daily evapotranspiration varies spatially and temporally according to the meteorological conditions [5]. Traditional field-based ET measurement techniques cannot be extended to large areas due to natural heterogeneity of the earth's surface and complexity of hydrologic processes and because of the need for measurements of many land surface parameters [6].

In recent decades, advancement in satellite technology has led to widespread application in remote sensing-based ET measurements. Remote sensing technology can provide cost-effectively frequent data on a relatively large scale that allow scientists and practitioners to monitor specific water resources in long terms basis [7]. Remote sensing datasets can provide land surface parameters which are crucial for estimation of ET such as albedo, surface temperature and vegetation indices. Several remote sensing-based ET measurements with different complexity have been implemented to map turbulent heat fluxes at various local and regional scales. In general, inputs to remote sensing-based ET models include surface temperature estimated from thermal bands of satellite datasets, albedo and vegetation indices retrieved from visible and near infrared spectral bands and meteorological data sets.

The Landsat- 8 was developed through an interagency partnership between the National Aeronautics and Space Administration (NASA) and the Department of the Interior U.S. Geological Survey (USGS). This new Landsat observatory launched on 11 February 2013 carrying two sensors, the Operational Land Imager (OLI) and the Thermal Infrared Sensor (TIRS) [8]. The advantage of using Landsat- 8 dataset for estimation of ET rests upon its high resolution of the visible and near infrared bands at $30 \mathrm{~m}$ spatial resolution and the thermal and at 100 
m spatial resolution.

Several methods for estimation of ET based on remote sensing techniques have shown reliable results over uniform hydro-climatic regions. These methods include the Surface Energy Balance Index (SEBI) [9], Two Source Model (TSM) [10], the Surface Energy Balance Algorithm for Land (SEBAL) [11], Simplified Surface Energy Balance Index (SSEBI) [12], The Surface Energy Balance System (SEBS) [13], ET Mapping Algorithm(ETMA) [14], Mapping evapotranspiration at high Resolution with Internalized Calibration (METRIC) which is a variant of SEBAL [15], and the simplified Surface Energy Balance (SSEB) [16].

One of the most appropriate algorithms recently used for remote sensing based estimation of daily evapotranspiration is the Surface Energy Balance System (SEBS) developed by Su [17]. The SEBS model showed a strong reasonability in several studies in various climatic and geographic conditions [18] [19] [20]. These input parameters in the SEBS model for reliable estimation of daily evapotranspiration are more suitable than other relevant models [15] [21].

The aim of this study is: First, estimation of SEBS based on Landsat 8 dataset for estimation of evapotranspiration in the study area; Second, estimation of ET using Penman-Monteith method and finally comparing results with observed values obtained from a lysimeter in the study area to evaluate the foregoing methods.

In this study, daily evapotranspiration over the Zayanderud Dam area in Isfahan province of Iran was estimated using the SEBS model. SEBS takes into account various physical and biological parameters of the land surface including Fractional Vegetation Cover (FC) (The fractional vegetation cover defines the partition between vegetated and non vegetated surfaces. In the SEBS algorithm, this parameter is used to determine other biogeophysical parameters such as Leaf Area Index (LAI), the excessive resistance term (kB-1), ground heat flux and surface temperature [13]), Leaf area index (LAI), The normalized difference vegetation index (NDVI), that were derived from multispectral bands Landsat 8 OLI image in this study. Thermal parameters of the Earth's surface were retrieved from Thermal bands of Landsat 8 satellite dataset.

Meteorological data obtained from two Synoptic weather stations (Chadegan and Daran) within the study area were used to measure reference crop evapotranspiration. Several models for estimation of ET based on meteorological data have been developed in various climatic and geographic conditions. Among those models, the Penman-Monteith FAO 56 (PMF-56) was introduced as a standard model to measure the reference crop evapotranspiration [22]. The ET values estimated by SEBS model showed strong correlation with the ET values based on Penman-Monteith equation. In order to validate the ET estimated by SEBS and Penman-Monteith method, results were compared with the observed values obtained from a lysimeter in the study area. The results are reliable for water supply managers to evaluate the current ET related to each land use and their influence to the water balance under probable changes within the Zayanderud Dam area. 


\section{Materials and Methods}

\subsection{Study Area}

The study was carried out in Zayanderud Dam area in Isfahan province of Iran and it extended from $50.35 \mathrm{E}$ to $50.45 \mathrm{E}$ and $32.42 \mathrm{~N}$ to $32.45 \mathrm{~N}$ (Figure 1 ). Mean annual rainfall in the study area is $324 \mathrm{~mm}$ and the average annual minimum and maximum temperature are 1 and $28^{\circ} \mathrm{C}$ respectively. In general, bare soils are the most dominant land use. The elevation of the study area is varying from 1943 to 2346 meters. Water body including the reservoir behind the dam is second largest land cover types in the study area (Figure 2). Zayanderud Dam on the Zayanderud River is one of the most important water reservoirs in central

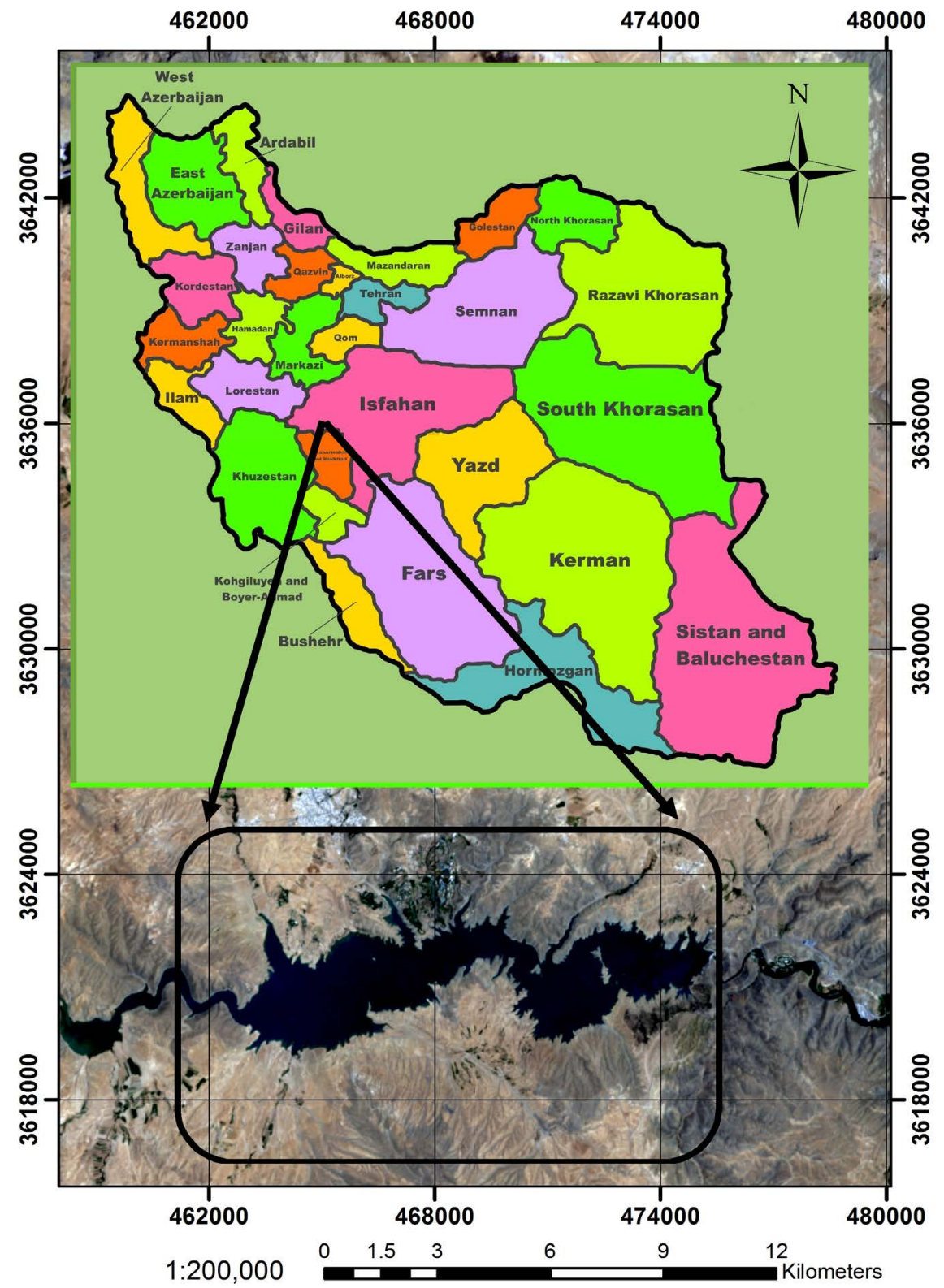

Figure 1. Study area. 


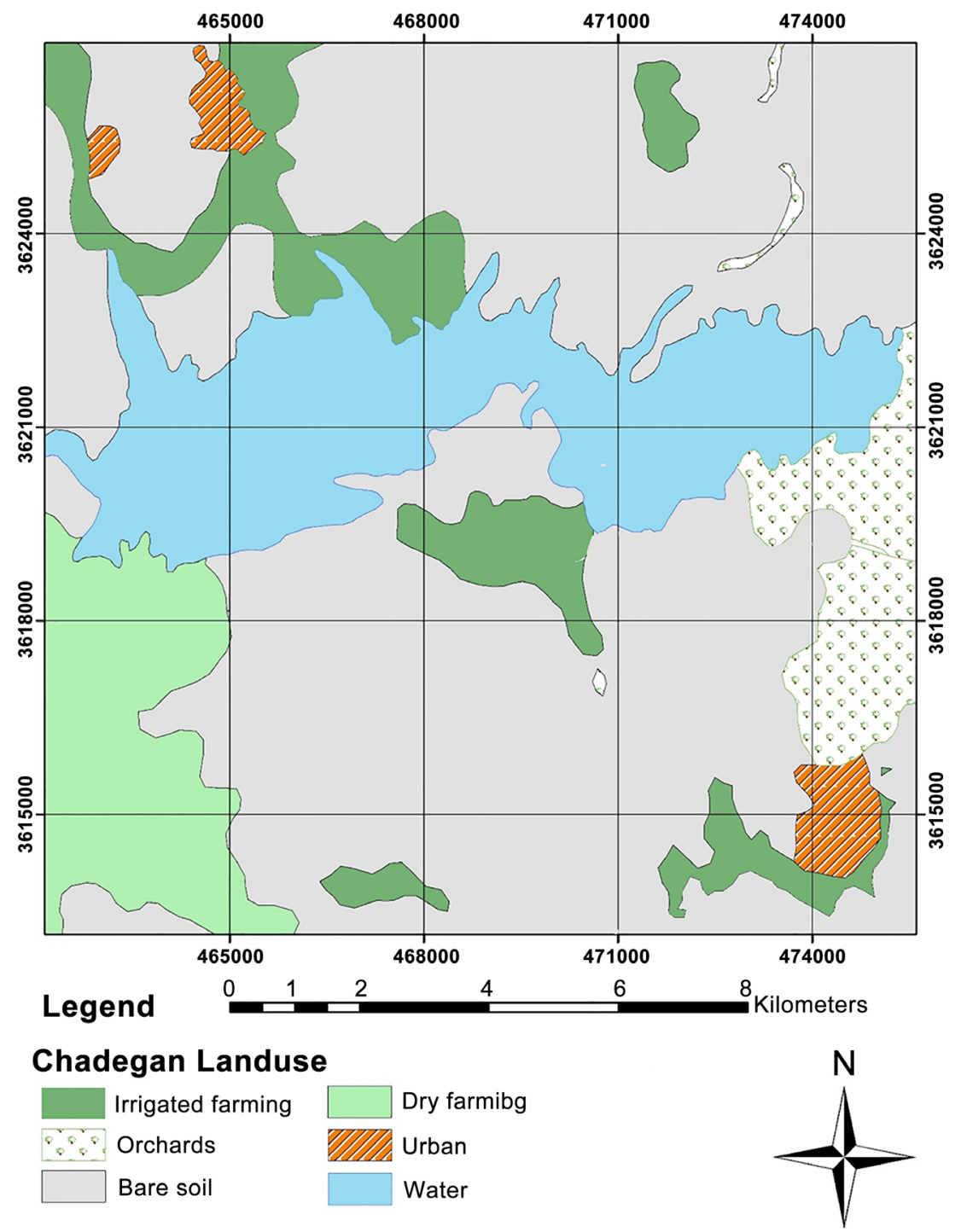

Figure 2. Landuse and land cover of the study area.

Iran and plays a vital rule in water supply management in this water scarce area. The Zayanderud River has provided the needs of water for important economic activities including agricultural, industrial and domestic consumptions. Several water projects have been constructed, or are under construction over the Zayanderud River. The Zayanderud Dam is the main water reservoir with 1450 MCM capacity and has been exploited since 1971. After the construction of the Zayanderud Dam, 90,000 hectares were added to the traditional agricultural activities. Presently, the surface water and groundwater dependent, is about 297,000 hectares [23]. The Zayanderud River has been confronting overuse and drought during past years due to huge industrial activities, traditional agriculture and population growth.

\subsection{Landsat 8 Dataset}

In this study, the Landsat 8 images are the main data to estimate daily evapo- 
transpiration and the evaporation fraction based on SEBS algorithm. We used three Landsat 8 datasets covering the study area from three different dates (14/07/2013, 17/07/2014, and 4/07/2015). The images were preprocessed by atmospheric corrections based on FLAASH model [24]. Thermal Infrared Sensor (TIRS) in Landsat 8 dataset consists of the band number 10 and 11 were used to retrieve the land surface temperature (LST). LST is one of the most important factors affecting the accuracy of the ET measurement. LST indicates the amount of energy and water may be available over the land surface .For calculation of LST, the spectral radiance values of pixels were converted into the at-sensor brightness temperatures using prelaunch calibration constants. Surface temperature (LST) was calculated using surface thermal emissivity and corrected for atmospheric absorption and re-emission values. The LST values were computed using a following formula [24]:

$$
\mathrm{LST}=\frac{K 2}{\ln \left(\frac{\varepsilon^{*} K 1}{P}+1\right)}
$$

where, $K 1$ and $K 2$ are prelaunch calibration constants; $\varepsilon$ is the narrowband emissivity extracted from a modification of the NDVI thresholds method [25]; and $P$ is the corrected thermal radiance derived using an algorithm given by [26] Emissivity values were calculated using the NDVI-based algorithm [25] The Normalized Difference Vegetation Index (NDVI) was computed from red and near-infrared bands.

Albedo was derived from atmospherically corrected surface reflectance observations collected by the first seven bands of the Landast 8 datasets in the Visible and Near-infrared (VNIR) spectrum [27].

Albedo $\left(R_{0}\right)=0.356 * B 1+0.13 * B 3+0.373 * B 4+0.085 * B 5+0.072 * B 7-0.0018$

The Leaf Area Index (LAI) computed for the study area using following formula developed by Choudhury [28]:

$$
\mathrm{LAI}=\frac{\log \left(1-f_{c}\right)}{-\Lambda}
$$

where, $f_{c}$ is The Fraction of Vegetation Cove computed with a formula [28] and $\Lambda$ is the leaf angle distribution ( 0.5 in this study).

\subsection{Surface Energy Balance System}

The Surface Energy Balance System was developed from SEBI concept [13] It is a single source model which consists of a set of tools for determining land surface parameters from remotely sensed data, a dynamic model for the determination of the roughness length for heat transfer, calculation of evaporative fraction based on energy balance at limiting meteorological conditions [17] [21]. In SEBS, ET is computed as the residual component from the land surface EB.

$$
R_{n}=G_{0}+H+\lambda E
$$

in which $R_{n}$ is the net flux, $G_{0}$ represents the soil heat, $H$ is the sensible heat flux, $\lambda . E$ is the turbulent latent heat flux, $\lambda$ is the latent heat of vaporization, and $E$ is the actual evaporation measured (The unit for all terms is watt per square meter). 
In the surface Energy Balance System a dynamic model is used to determine thermal roughness [21]. SEBS uses bulk atmospheric similarity theory for planetary boundary layer (PBL) scaling [29], and the Monin-Obukhov similarity theory [30] for atmospheric surface layer scaling. These theories allow SEBS to be applied for estimation of ET in different stable atmospheric regimes in both regional and local scales.

To estimate evaporative fraction both dry and wet limiting cases are required. Under the dry limiting conditions, due to low moisture rate in soil, the latent heats $\left(\lambda E_{\mathrm{dry}}\right)$ is considered to be zero while the sensible heat flux is in the maximum value [5].

$$
\begin{gathered}
\lambda E_{\text {dry }}=R_{n}-G_{0}-H_{\text {dry }} \equiv 0 \\
H_{\text {dry }}=R_{n}-G_{0}
\end{gathered}
$$

In the wet limit cases the evaporation rate in its maximum value $\left(\lambda E_{\text {wet }}\right)$ because the evaporation is only limited by the available energy under the land surface and atmospheric conditions. Accordingly, the sensible heat flux $\left(H_{\text {wet }}\right)$ is in the Minimum value.

$$
\lambda E_{\text {wet }}=R_{n}-G_{0}-H_{\text {wet }} \text { or } H_{\text {wet }}=R_{n}-G_{0}-\lambda E_{\text {wet }}
$$

Then evaporative fraction can be calculated as following:

$$
\Lambda_{r}=\frac{\lambda E}{\lambda E_{\text {wet }}}=1-\frac{\lambda E_{\text {wet }}-\lambda E}{\lambda E_{\text {wet }}}=1-\frac{H-H_{\text {wet }}}{H_{\text {dry }}-H_{\text {wet }}}
$$

in which $H$ is the actual sensible heat flux based on bulk atmospheric similarity approach. In SEBS algorithm $H$ is limited by the $H_{\text {dry }}$ and $H_{\text {wet }}$ limiting conditions.

Finally, the daily actual ET can be formulated as Eq. 6

$$
\mathrm{AET}=8.64 * 10^{7} * \Lambda^{24} * \frac{R_{n}-G_{0}}{\lambda \rho_{w}}
$$

where $\rho_{\mathrm{w}}$ is the density of water $\left(\mathrm{kg} / \mathrm{m}^{3}\right), \Lambda^{24}$ is the daily evaporative fraction in millimeters per day.

\subsection{Meteorological Data}

Meteorological data in this study were used to determine the Planetary Boundary Layers [5]. Two different synoptic weather stations located in the study area (Chadegan and Daran) were used to obtain the meteorological data including mean temperature, wind speed, surface pressure, humidity, solar radiation, surface pressure. The data were collected during 2013 to 2015 (Table 1).

\subsection{Penman-Monteith Method}

The Penman-Monteith equation was applied to derive actual evapotranspiration using the meteorological dataset within the study area [22]:

$$
E T_{0}=\frac{0.408 \Delta\left(R_{n}-G_{0}\right)+\gamma \frac{900}{T+273.15} U_{2}\left(e_{a}-e_{s}\right)}{\Delta+\gamma\left(1+0.34 U_{2}\right)}
$$

where $E T_{\mathrm{o}}$ is the reference evapotranspiration [mm/day], $R_{n}$ is net radiation at 
crop surface $\left(\mathrm{MJ} / \mathrm{m}^{2} \cdot\right.$ day $), G$ is the soil heat flux density $\left(\mathrm{MJ} / \mathrm{m}^{2} \cdot\right.$ day $), T$ is mean daily air temperature $\left({ }^{\circ} \mathrm{C}\right), u_{2}$ is the wind speed $(\mathrm{m} / \mathrm{s}), \quad e_{s}$ saturation vapor pressure $(\mathrm{kPa}), e_{a}$ is the actual vapor pressure $(\mathrm{kPa}), \Delta$ is slope vapor pressure curve $\left(\mathrm{kPa} /{ }^{\circ} \mathrm{C}\right), \quad \gamma$ psychrometric constant $\left(\mathrm{kPa} /{ }^{\circ} \mathrm{C}\right)$.

\section{Results}

The main purpose of this study was estimation of daily evapotranspiration using SEBS algorithm in the Zayanderud Dam in Isfahan province of Iran. Land surface parameters were extracted from three Landsat 8 images covering the study area. Meteorological parameters obtained from two weather stations. Sensible heat flux and latent heat flux at the wet limit were computed using SEBS algorithm. Then, net flux and daily evapotranspiration were calculated. In the next step, the Penman-Monteith Equation (Eq. 7) was applied to calculate the actual daily evapotranspiration (Table 2). Finally, results compared with a ground truth data obtained from a lysimeter within the study area (Figures 3(a)-(c)). While estimated evapotranspiration values using both SEBS and Penman-Monteith showed very close results, the SEBS estimated ET values demonstrated higher correlation with the observed values (Table 3).

Results showed that spatial distribution of evapotranspiration over the study area is varying due to changes in landuse and landcover, physical characteristics of soil and atmospheric parameters. Using remote sensing techniques we could evaluate the spatial distribution of evapotranspiration over the study area. In this

Table 1. Meteorological data from daran and Chadegan station.

\begin{tabular}{ccccccccccc}
\hline Date & Time & $\rho$ & $\Delta$ & $P$ & $e_{s}$ & $e_{a}$ & $K \downarrow$ & $R H$ & $U$ & $T$ \\
\hline $14 / 07 / 2013$ & $7: 10$ & 1.12 & 0.197 & 101.272 & 3.32 & 1.145 & 752 & 34.5 & 3.6 & 25.8 \\
$17 / 07 / 2014$ & $7: 08$ & 1.13 & 0.197 & 101.272 & 3.32 & 0.846 & 753 & 25.5 & 1.5 & 25.8 \\
$04 / 07 / 2015$ & $7: 08$ & 1.11 & 0.197 & 101.272 & 3.32 & 0.697 & 753 & 21 & 2.4 & 25.8 \\
\hline
\end{tabular}

( $\rho$ is density of air $\left(\mathrm{kg} / \mathrm{rm}^{3}\right), \Delta$ is slope vapor pressure curve $\left(\mathrm{kPa} /{ }^{\circ} \mathrm{C}\right), \mathrm{P}$ is atmospheric pressure $(\mathrm{kPa}), \mathrm{e}_{\mathrm{s}}$ is saturation vapor pressure $(\mathrm{kPa}), \mathrm{e}_{\mathrm{a}}$ is the actual vapor pressure $(\mathrm{kPa}), \bigotimes K \downarrow$ is the incoming short wave radiation $\left(\mathrm{Wm}^{2}\right), \mathrm{RH}$ is relative humidity, $\mathrm{U}$ is the wind speed $(\mathrm{m} / \mathrm{s}), \mathrm{T}$ is mean daily air temperature $\left.\left({ }^{\circ} \mathrm{C}\right)\right)$.

Table 2. ET estimated from Landsat 8 data using SEBS algorithm.

\begin{tabular}{ccccc}
\hline Date of Image & Minimum ET & Maximum ET & Mean ET & $\begin{array}{c}\text { Standard } \\
\text { deviation }\end{array}$ \\
\hline $2013-07-14$ & 6.81 & 13.69 & 11.20 & 0.740 \\
$2014-07-17$ & 5.48 & 12.89 & 10.58 & 0.810 \\
$2015-07-04$ & 4.95 & 10.80 & 8.94 & 0.684 \\
\hline
\end{tabular}

Table 3. Estimated ET and actual ET values.

\begin{tabular}{cccc}
\hline Date & Lysimeter & Penman_Montith $(\mathrm{mm})$ & SEBS $(\mathrm{mm})$ \\
\hline $7 / 14 / 2013$ & 12 & 9.46 & 11.2 \\
$7 / 17 / 2014$ & 11 & 8.11 & 10.58 \\
$7 / 4 / 2015$ & 11 & 8.08 & 8.94 \\
\hline
\end{tabular}




\section{$7 / 14 / 2013$}

12
11
10
9
8
7
6
5
4
3
2
1
0
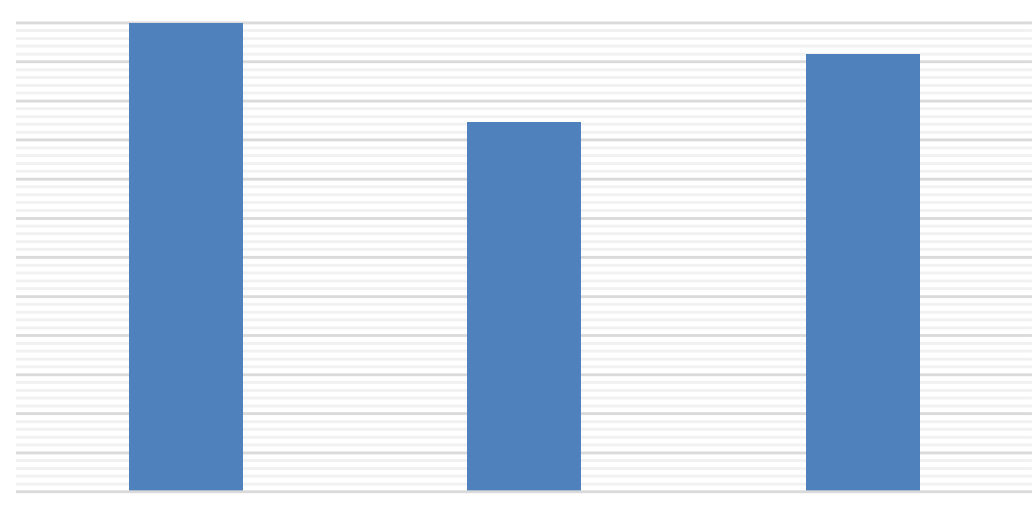

Lysimeter

Penman-Montheith

SEBS

(a)

\section{$7 / 17 / 2014$}

$$
\begin{array}{r}
12 \\
11 \\
10 \\
9 \\
8 \\
7 \\
6 \\
5 \\
4 \\
3 \\
2 \\
1 \\
0
\end{array}
$$

12
11
10
9
8
7
6
5
4
3
2
1
0

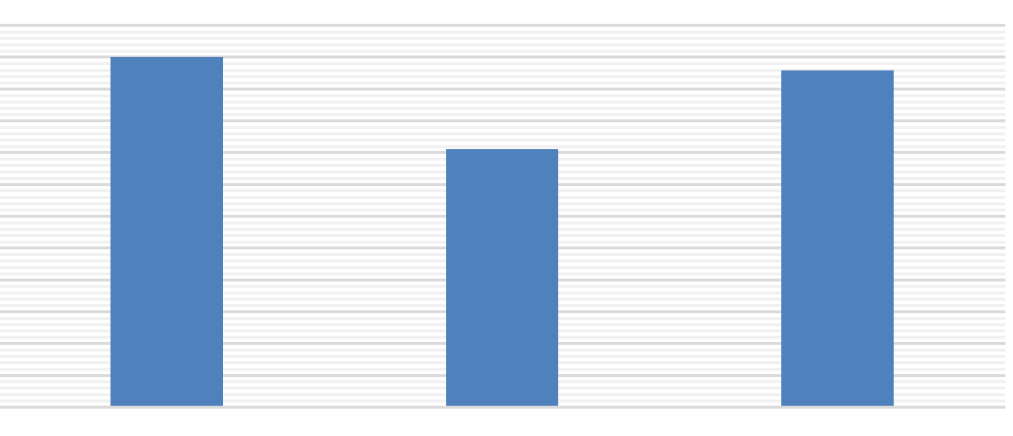

Lysimeter

Penman-Montheith

SEBS

(b)

$7 / 4 / 2015$

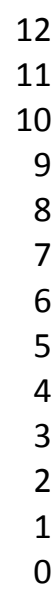

1
0
9
8
7
6
5
4
3
2
1
0

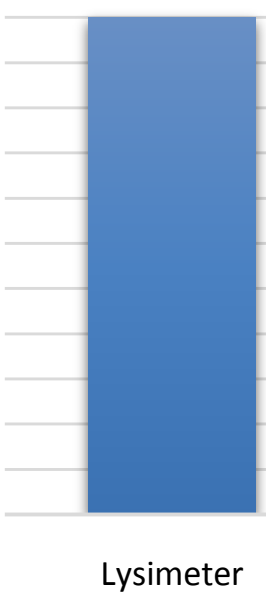

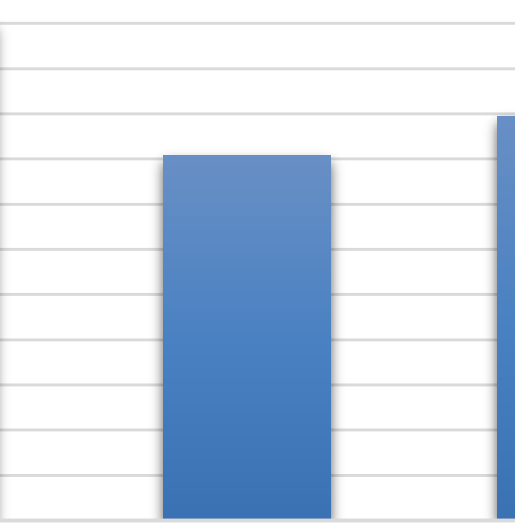

Penman-Montheith

(c)

Figure 3. Comparison of daily ET estimated by three different methods in each year. 

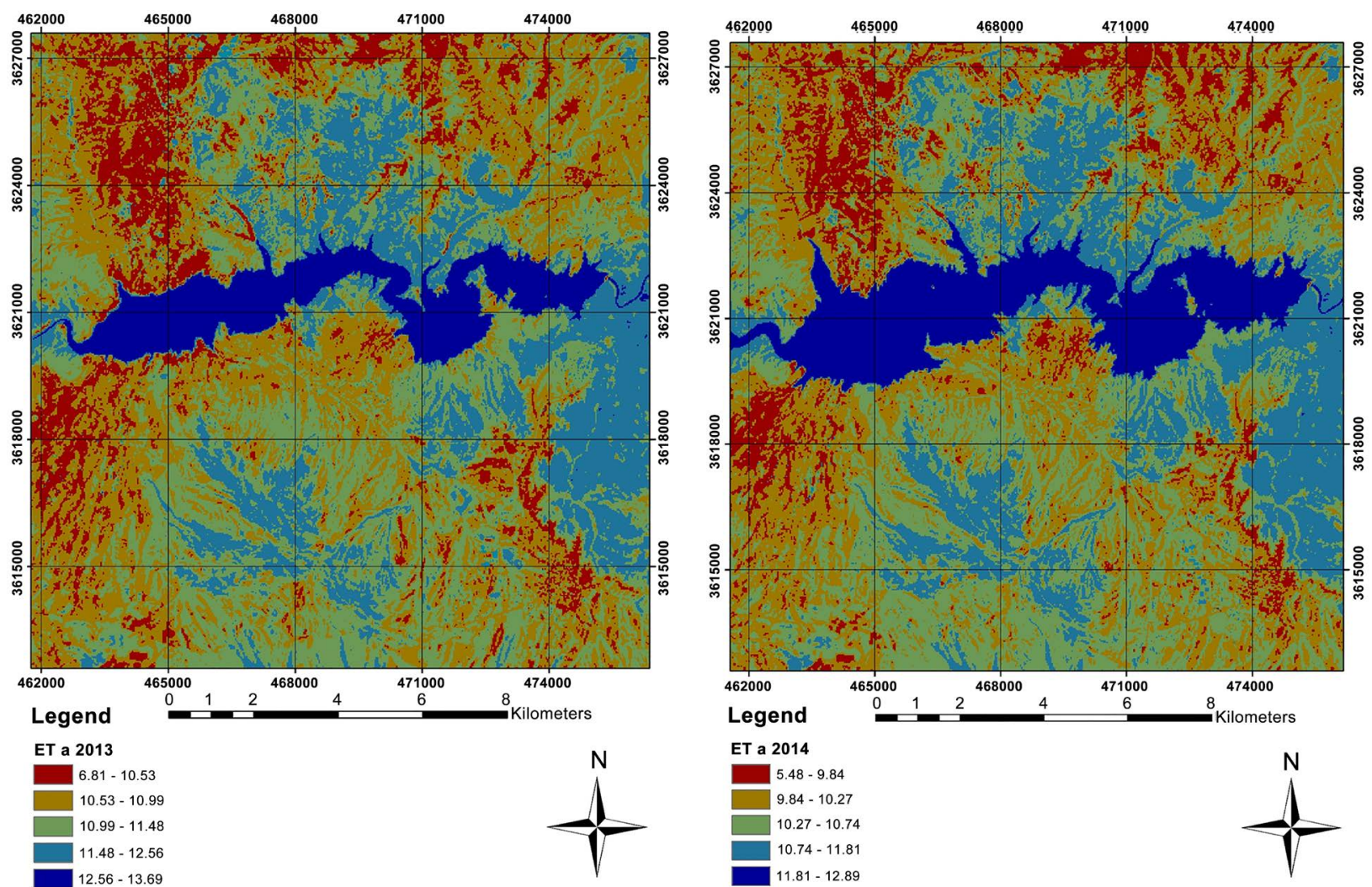

(a)

(b)

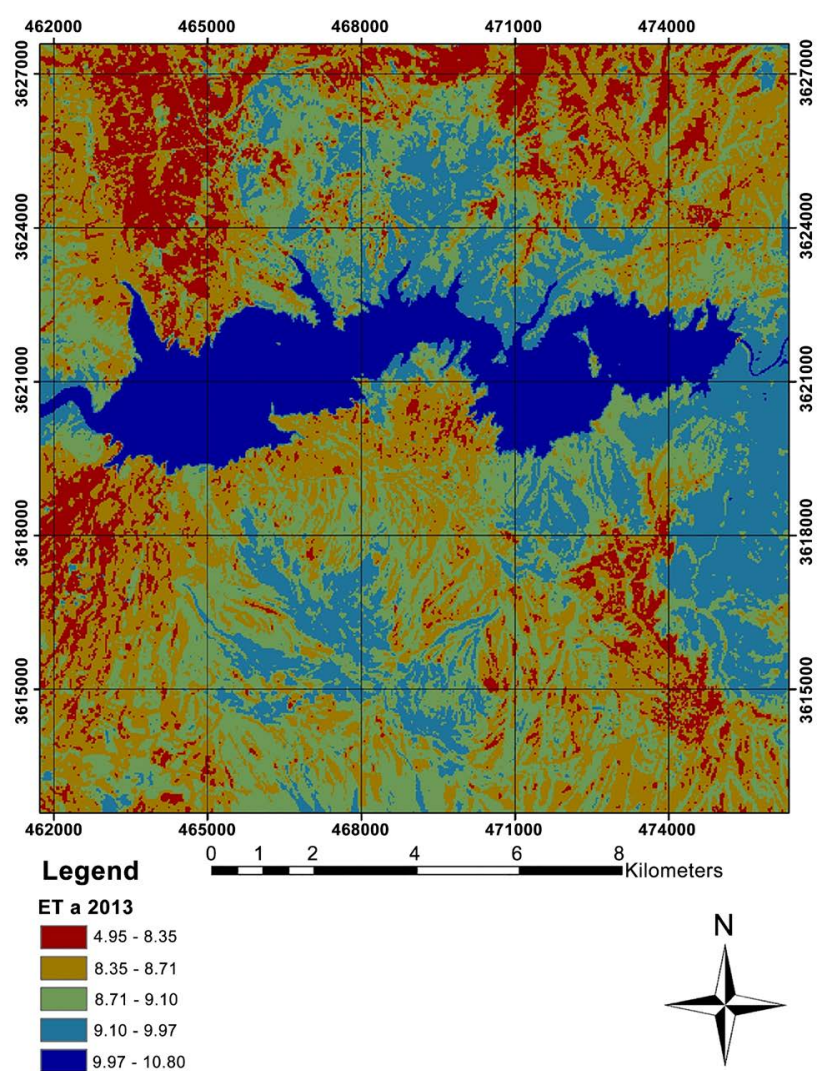

(c)

Figure 4. (a) Estimated ET for 14 July 2013; (b) ET estimated for 17 July 2014; (c) Estimated ET for 4 July 2015. 
study, the SEBS estimated ET values varies from 4.95 to 10.80 for the year 2015 . There is also a significant difference between maximum and minimum ET values in different part of the study area for the year 2013 and 2014 (Table 2). By combination of different layers in GIS we could analyze and evaluate the effective parameters on ET rate. Moreover, the changes in the ET rates over time were investigated by implementing multi temporal satellite dataset.

\section{Conclusion}

Using remotely sensed derived parameters of the earth's surface and meteorological data in the SEBS algorithm we could estimate the daily evapotranspiration within the study region. Moreover, the spatial distribution of ET rate within the study region was mapped which is the advantage of this approach over the ground-based ET measurements. Using the SEBS algorithm along with an accurate Land use and Land cover information will enable us to relate the rate of the ET in a specific region to their corresponding land use types. Variation in land use caused spatial changes in ET rate over the study area (Figure 2). (Figures 4(a)-(c)) show the spatial variations of ET estimates based on Landsat 8 data in the study area in three different dates. The results indicate ET for water bodies and irrigated agriculture is high, while for bare soil and urban areas ET is low. This indicates the rate of ET is controlled by types of land use and water availability at the same time. According to the results, the highest rate of ET is occurring over the reservoir behind the dam which is the main land cover types within the study area. Images showed that, although the size of reservoir behind the Zayanderud Dam increased from 2013 to 2015, the rate of ET over the reservoir decreased. Mean SEBS estimated ET values were calculated 8.94, 10.58 and 11.20 for 2013, 2014 and 2015 respectively. Agricultural lands including dry and irrigated farming are second largest land use in study area. ET values over the irrigated farming are much more than ET values in dry farming. This may draw the attention of the water supply and land use managers to adjust the agricultural activities toward having more dry farming lands rather than irrigated farming. The results could have been more reliable if we had more available lysimeters distributed over the study area to validate the ET estimated from SEBS algorithm more accurately.

\section{Acknowledgements}

This research was carried out as part of the first author's M.Sc thesis in Geological Remote Sensing at Isfahan (Khorasgan) Branch, Islamic Azad University, Isfahan, Iran.

\section{References}

[1] Talaee, P.H., Some'e, B.S. and Ardakani, S.S. (2014) Time Trend and Change Point of Reference Evapotranspiration over Iran. Theoretical and Applied Climatology, 116, 639-647. https://doi.org/10.1007/s00704-013-0978-x

[2] Muthuwatta, L.P., Bos, M. and Rientjes, T. (2010) Assessment of Water Availability 
and Consumption in the Karkheh River Basin, Iran-Using Remote Sensing and Geo-Statistics. Water Resources Management, 24, 459-484. https://doi.org/10.1007/s11269-009-9455-9

[3] Thornthwaite, C.W. and Mather, J.R. (1955) The Water Balance. Publications in climatology, 8, 5-86.

[4] DeBruin, H.A. (2009) Time to Think: Reflections of a Pre-Pensioned Scintillometer Researcher. Bulletin of the American Meteorological Society, 90, ES17-ES26. https://doi.org/10.1175/2008bams2704.2

[5] Su, Z., Yacob, A., Wen, J., Roerink, G., He, Y., Gao, B. and van Diepen, C. (2003) Assessing Relative Soil Moisture with Remote Sensing Data: Theory, Experimental Validation, and Application to Drought Monitoring over the North China Plain. Physics and Chemistry of the Earth, Parts $A / B / C, 28,89-101$.

[6] Idso, S.B., Jackson, R.D. and Reginato, R.J. (1975) Estimating Evaporation: A Technique Adaptable to Remote Sensing. Science, 189, 991-992. https://doi.org/10.1126/science.189.4207.991

[7] Jha, M.K. and Chowdary, V. (2007) Challenges of Using Remote Sensing and GIS in Developing Nations. Hydrogeology Journal, 15, 197-200.

https://doi.org/10.1007/s10040-006-0117-1

[8] Roy, D.P., Wulder, M., Loveland, T., Woodcock, C., Allen, R., Anderson, M. and. Kennedy, R. (2014) Landsat-8: Science and Product Vision for Terrestrial Global Change Research. Remote Sensing of Environment, 145, 154-172.

[9] Menenti, M. and Choudhury, B. (1993) Parameterization of Land Surface Evapotranspiration Using a Location Dependent Potential Evapotranspiration and Surface Temperature Range. Exchange Processes at the Land Surface for a Range of Space and Time Scales, IAHS Publication, 212, 561-568.

[10] Norman, J.M., Kustas, W.P. and Humes, K.S. (1995) Source Approach for Estimating Soil and Vegetation Energy Fluxes in Observations of Directional Radiometric Surface Temperature. Agricultural and Forest Meteorology, 7, 263-293.

[11] Bastiaanssen, W., Menenti, M., Feddes, R. and Holtslag, A. (1998) A Remote Sensing Surface Energy Balance Algorithm for Land (SEBAL). 1. Formulation. Journal of hydrology, 212, 198-212.

[12] Roerink, G., Su, Z. and Menenti, M. (2000) S-SEBI: A Simple Remote Sensing Algorithm to Estimate the Surface Energy Balance. Physics and Chemistry of the Earth, Part B: Hydrology, Oceans and Atmosphere, 25, 147-157.

[13] Su, Z. (2002) The Surface Energy Balance System (SEBS) for Estimation of Turbulent Heat Fluxes. Hydrology and Earth System Sciences, 6, 85-100. https://doi.org/10.5194/hess-6-85-2002

[14] Loheide, S.P. and Gorelick, S.M. (2005) A Local-Scale, High-Resolution Evapotranspiration Mapping Algorithm (ETMA) with Hydroecological Applications at Riparian Meadow Restoration Sites. Remote Sensing of Environment, 98, 182-200.

[15] Allen, R.G., Tasumi, M. and Trezza, R. (2007) Satellite-Based Energy Balance for Mapping Evapotranspiration with Internalized Calibration (METRIC)-Model. Journal of Irrigation and Drainage Engineering, 133, 380-394. https://doi.org/10.1061/(ASCE)0733-9437(2007)133:4(380)

[16] Senay, G.B., Budde, M., Verdin, J.P. and Melesse, A.M. (2007) A Coupled Remote Sensing and Simplified Surface Energy Balance Approach to Estimate Actual Evapotranspiration from Irrigated Fields. Sensors, 7, 979-1000.

https://doi.org/10.3390/s7060979

[17] Su, Z. (2002) A Surface Energy Balance System (SEBS) for Estimation of Turbulent 
Heat Fluxes from Point to Continental Scale. Paper presented at the Spectra Workshop.

[18] Ma, W., Hafeez, M., Ishikawa, H. and Ma, Y. (2013) Evaluation of SEBS for Estimation of Actual Evapotranspiration Using ASTER Satellite Data for Irrigation Areas of Australia. Theoretical and Applied Climatology, 112, 609-616. https://doi.org/10.1007/s00704-012-0754-3

[19] Gokmen, M., Vekerdy, Z., Verhoef, A., Verhoef, W., Batelaan, O. and Van der Tol, C. (2012) Integration of Soil Moisture in SEBS for Improving Evapotranspiration Estimation under Water Stress Conditions. Remote Sensing of Environment, 121, 261-274.

[20] Ershadi, A., McCabe, M., Evans, J.P. and Walker, J.P. (2013) Effects of Spatial Aggregation on the Multi-Scale Estimation of Evapotranspiration. Remote Sensing of Environment, 131, 51-62.

[21] Su, Z., Schmugge, T., Kustas, W. and Massman, W. (2001) An Evaluation of Two Models for Estimation of the Roughness Height for Heat Transfer between the Land Surface and the Atmosphere. Journal of Applied Meteorology, 40, 1933-1951. https://doi.org/10.1175/1520-0450(2001)040<1933:AEOTMF>2.0.CO;2

[22] Allen, R.G., Pereira, L.S., Raes, D. and Smith, M. (1998) Crop EvapotranspirationGuidelines for Computing Crop Water Requirements-FAO Irrigation and Drainage Paper No. 56. FAO, Rome, Italy, 300 p.

[23] Morid, S. (2003) Adaptation to Climate Change to Enhance Food Security and Environmental Quality: Zayandeh Rud Basin, Iran.

[24] Kaufman, Y.J., Wald, A.E., Remer, L.A., Gao, B.-C., Li, R.-R. and Flynn, L. (1997) The MODIS 2.1- $\mu \mathrm{m}$ Channel-Correlation with Visible Reflectance for Use in Remote Sensing of Aerosol. IEEE Transactions on Geoscience and Remote Sensing, 35, 1286-1298. https://doi.org/10.1109/36.628795

[25] Sobrino, J.A., Jiménez-Muñoz, J.C. and Paolini, L. (2004) Land Surface Temperature Retrieval from LANDSAT TM 5. Remote Sensing of Environment, 90, 434-440.

[26] Wukelic, G., Gibbons, D., Martucci, L. and Foote, H. (1989) Radiometric Calibration of Landsat Thematic Mapper Thermal Band. Remote Sensing of Environment, 28, 339-347.

[27] Liang, S. (2001) Narrowband to Broadband Conversions of Land Surface Albedo I: Algorithms. Remote Sensing of Environment, 76, 213-238.

[28] Choudhury, B.J. (1987) Relationships between Vegetation Indices, Radiation Absorption, and Net Photosynthesis Evaluated by a Sensitivity Analysis. Remote Sensing of Environment, 22, 209-233.

[29] Wyngaard, J.C. (1990) Scalar Fluxes in the Planetary Boundary Layer-Theory, Modeling, and Measurement. Boundary-Layer Meteorology, 50, 49-75. https://doi.org/10.1007/BF00120518

[30] Monin, A. and Obukhov, A. (1954) Basic Laws of Turbulent Mixing in the Surface Layer of the Atmosphere. Tr. Akad. Nauk SSSR Geophiz. Inst., 151, 163-187. 
Submit or recommend next manuscript to SCIRP and we will provide best service for you:

Accepting pre-submission inquiries through Email, Facebook, LinkedIn, Twitter, etc. A wide selection of journals (inclusive of 9 subjects, more than 200 journals)

Providing 24-hour high-quality service

User-friendly online submission system

Fair and swift peer-review system

Efficient typesetting and proofreading procedure

Display of the result of downloads and visits, as well as the number of cited articles Maximum dissemination of your research work

Submit your manuscript at: http://papersubmission.scirp.org/

Or contact ojg@scirp.org 